\title{
Naturally occurring arsenic in terrestrial geothermal systems of western Anatolia, Turkey: Potential role in contamination of freshwater resources
}

\author{
Jochen Bundschuh ${ }^{\mathrm{a}, \mathrm{b}, *}$, Jyoti Prakash Maity ${ }^{\mathrm{c}}$, Bibhash Nath ${ }^{\mathrm{d}}$, Alper Baba ${ }^{\mathrm{e}}$, Orhan Gunduz ${ }^{\mathrm{f}}$, \\ Thomas R. Kulp ${ }^{g}$, Jiin-Shuh Jean ${ }^{\mathrm{h}}$, Sandeep Kar ${ }^{\mathrm{h}}$, Huai-Jen Yang ${ }^{\mathrm{h}}$, Yu-Jung Tseng ${ }^{\mathrm{c}}$, \\ Prosun Bhattacharya ${ }^{\mathrm{b}}$, Chien-Yen Chen ${ }^{\mathrm{c}, * *}$ \\ a Faculty of Engineering and Surveying E National Centre of Engineering in Agriculture, University of Southern Queensland, Toowoomba, Queensland 4350, Australia

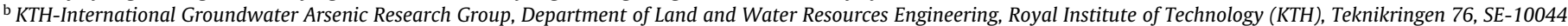 \\ Stockholm, Sweden \\ ${ }^{c}$ Department of Earth and Environmental Sciences, National Chung Cheng University, 168 University Road, Ming-Shung, Chiayi County 62102, Taiwan \\ d School of Geosciences, University of Sydney, Sydney, NSW 2006, Australia \\ e Izmir Institute of Technology, Faculty of Engineering, Department of Civil Engineering, 35430-Gulbahce, Urla, Izmir, Turkey \\ ${ }^{\mathrm{f}}$ Dokuz Eylul University, Department of Environmental Engineering, Buca-35160, Izmir, Turkey \\ g Department of Geological Sciences and Environmental Studies, Binghamton University, Binghamton, NY, USA \\ h Department of Earth Sciences, National Cheng Kung University, 1 University Road, Tainan 70101, Taiwan
}

\section{H I G H L I G H T S}

- Potential environmental impact of high arsenic from geothermal sources was identified.

- Geothermal waters from deep wells are characterized by $\mathrm{Na}-\mathrm{HCO}_{3}$ type.

- Hot spring fluids are characterized by $\mathrm{Ca}-\mathrm{HCO}_{3}$ type.

- As(III) is the dominant species in both deep wells and hot spring fluids.

- Mixing of geothermal waters containing As is responsible for environmental impact.

\section{A R T I C L E I N F O}

\section{Article history:}

Received 3 September 2012

Received in revised form 7 January 2013

Accepted 17 January 2013

Available online 28 January 2013

\section{Keywords:}

Arsenic

Geothermal wells

Hot springs

Environmental contamination

Turkey

\begin{abstract}
A B S T R A C T
Arsenic (As) contamination in terrestrial geothermal systems has been identified in many countries worldwide. Concentrations higher than $0.01 \mathrm{mg} / \mathrm{L}$ are detrimental to human health. We examined potential consequences for As contamination of freshwater resources based on hydrogeochemical investigations of geothermal waters in deep wells and hot springs collected from western Anatolia, Turkey. We analyzed samples for major ions and trace element concentrations. Temperature of geothermal waters in deep wells showed extreme ranges $\left(40\right.$ and $\left.230^{\circ} \mathrm{C}\right)$, while, temperature of hot spring fluids was up to $90^{\circ} \mathrm{C}$. The Piper plot illustrated two dominant water types: $\mathrm{Na}-\mathrm{HCO}_{3}{ }^{-}$type for geothermal waters in deep wells and $\mathrm{Ca}-\mathrm{HCO}_{3}{ }^{-}$type for hot spring fluids. Arsenic concentration ranged from 0.03 to $1.5 \mathrm{mg} / \mathrm{L}$. Dominance of reduced As species, i.e., As(III), was observed in our samples. The Eh value ranged between -250 and $119 \mathrm{mV}$, which suggests diverse geochemical conditions. Some of the measured trace elements were found above the World Health Organization guidelines and Turkish national safe drinking water limits. The variation in $\mathrm{pH}$ (range: 6.4-9.3) and As in geothermal waters suggest mixing with groundwater. Mixing of geothermal waters is primarily responsible for contamination of freshwater resources and making them unsuitable for drinking or irrigation.
\end{abstract}

(c) 2013 Elsevier B.V. All rights reserved.

\footnotetext{
* Corresponding author at: Faculty of Engineering and Surveying, University of Southern Queensland, Toowoomba, Queensland 4350, Australia.

Tel.: +61 746312694 .

** Corresponding author.

E-mail addresses: jochen.bundschuh@yahoo.com (J. Bundschuh), yen@eq.ccu.edu.tw (C.-Y. Chen).
}

\section{Introduction}

Arsenic (As) is a well-known toxic and carcinogenic metalloid found in a wide variety of chemical forms. Under changes in geochemical and microbiological conditions As can be transformed and mobilized in the environment. The presence of As, above the level safe for human consumption, has been detected widely in groundwater and hydrothermal systems, currently 
recognized as a major global public-health issue [1-3]. The occurrence of As in terrestrial geothermal systems has been identified in many areas of the world, including Alaska, western USA, Mexico, Central America, northern Chile, Kamchatka, Japan, Taiwan, Philippines, Indonesia, Papua New Guinea, New Zealand, Iceland and France $[2,4]$. It has also been recognized that both geogenic and anthropogenic processes control the occurrence on local and regional scales in different parts of the world [5-7].

In several geographical locations such as Turkey, India, Bangladesh and Taiwan, As occurs naturally in subsurface strata within the volcanic and sedimentary formations as well as in the areas of geothermal systems associated with tectonic activity. Arsenic concentrations found in geothermal waters are highly variable depending on the geological and tectonic setting, the hydrodynamic pattern, and the thermodynamic conditions especially pressure and temperature. The release of As in geothermal waters further depends on the availability of As source rocks and minerals (both primary and secondary), geochemical conditions (predominantly $\mathrm{pH}$ and redox state), and microbial activity $[2,4]$. In geothermal environments, mobility of As can be partly controlled by its chemical speciation. The dominant As species in a given environmental setting is controlled by many parameters, such as $\mathrm{pH}$, temperature, adsorption and dissolution reactions and redox conditions which are driven by the presence of organic matter and inorganic electron donors such as sulfides [8-13]. Arsenic is generally released from the host rock by dissolution under reducing conditions, where high residence time, and high temperature and pressure of the fluids favor its mobilization $[2,14]$. The presence of As in geothermal systems, principally in geothermal deep wells and/or geothermal surface manifestations, such as hot springs, fumaroles and solfataras, may have severe environmental consequences, as the rising geothermal water may contaminate "cold" groundwater aquifers, vadose zone, surface waters, and other surface environments [2].

During last few decades, environmental impacts of geothermal energy production have become a key research topic in Turkey [15-17]. The contamination of surface waters and groundwaters with hydrothermally derived As is the most severe consequence of geothermal energy production [18,19]. Drinking and irrigation water resources, such as surface waters and groundwater near geothermal fields, have become polluted with significant levels of As and other toxic elements by the wastewater derived from geothermal plants [20-22]. Therefore, this study was aimed to investigate the geochemical behavior and characteristics of As in geothermal waters of western Anatolia, Turkey. This study also focuses on the behavior of contaminants in surface environments associated with mixing of geothermal waters with freshwater resources.

\section{Geological setting of the study area}

The study area, western Anatolia, Turkey, is located on a seismically active crust with $\mathrm{N}-\mathrm{S}$ extensional regime [23]. Plate movements associated with tectonic activities have controlled the geography of the region. Under the extensional regime, the upper crust of western Anatolia is broken by normal faults that form E-W oriented graben systems (Fig. 1). The most important of these graben systems are Gediz, Simav, Küçük and Büyük [24,25].

The Gediz graben is $140 \mathrm{~km}$ long and $3-40 \mathrm{~km}$ wide where fractured rocks of the Menderes Massif (such as mica-schist, gneiss and marbles) form the reservoir rock. The cap rock of the geothermal waters include clay-rich intervals within the Neogene sedimentary units [26].

The Simav graben is located in the northeastern corner of the Simav plain. This is an E-W trending Pliocene to Quaternary asymmetric depression that developed on the older NE-SW trending Miocene basin in Western Anatolia [27]. The graben is bounded from the south by the Simav fault, which is an active oblique-slip normal fault. The graben fill associated with the Simav fault is composed of semilithified boulder conglomerate and sandstone. The northern part of the Simav graben is known as Akdere basin, which consists of coarse clastics and Naşa volcanics. Three geothermal systems (Eynal, Naşa and Citgöl) have formed in this graben.

The Küçük Menderes Graben is $80 \mathrm{~km}$ long and $3-10 \mathrm{~km}$ wide system. This is a part of the horst-graben system of western Anatolia and is bounded by the Bozdağ horst to the north and the Aydın horst to the south.

The Büyük Menderes graben is $200 \mathrm{~km}$ long and $10-20 \mathrm{~km}$ wide system which is bordered by well-developed normal fault systems. Many geothermal springs are associated with the bounding normal faults. North striking transverse faults dissect the northern margin of the graben and commonly extend into the Menderes massif Ten hottest geothermal systems in Turkey, Kizildere, Germencik, Yılmazköy, Sultanhisar, Atca, Kavaklıdere, Pamukoren, Umurlu, Hıdırbeyli, Guzelkoy are located in the Büyük Menderes graben. Most of the geothermal systems in this graben have two reservoirs. The reservoir fluid is contained mainly in Paleozoic fractured rocks consisting of quartz schist, gneiss, and karstic marbles of the Menderes Massif where the second fluid reservoir is contained in Neogene sandstones and conglomerates. The impermeable claystone and mudstone of Neogene age forms the cap rock. The heat source is a magmatic intrusion along the young faults related to graben tectonic activity.

\section{Materials and methods}

\subsection{Sample collection and preservation}

Geothermal waters were collected from different hot springs $(n=12)$ and deep geothermal wells $(n=19)$ of western Anatolia, Turkey. The locations of these sampling regions are given in Table 1 and are shown in Fig. 1. The samples were collected after filtering through $0.45 \mu \mathrm{m}$ filter syringes, in a dark, sterilized glass (BD anaerobic Vacutainer) tubes. Parts of the samples were preserved with a few drops of concentrated nitric acid for cations and trace element analysis, whereas, un-preserved samples were collected for anion analysis. Electrical conductivity (EC), total dissolved solids (TDS), dissolved oxygen (DO), temperature, salinity, $\mathrm{pH}$, and Eh were measured in the field. A portable multi parameter probe (Hach-Lange HQ40d) was used to measure all the field parameters.

\subsection{Chemical analysis}

The cation and anion concentrations were analyzed using an ion chromatograph (IC) (Dionex, CA, USA). Dissolved organic carbon (DOC) was measured using C/N analyzer (Model: 2100, Analytik, Jena), detection limit $0.5 \mathrm{mg} / \mathrm{L}$. The trace element concentrations were analyzed using an Agilent 7500cs (Agilent Technologies, Tokyo, Japan) inductively coupled plasma mass spectrometer (ICPMS). The detailed procedure was outlined previously by Nath et al. [5] and Liu et al. [28]. The speciation of arsenic among the arsenite (As-III), arsenate (As-V), monomethyl arsenic (MMA), dimethyl arsenic (DMA), and arsenobetaine (AsB) forms was measured by ICP-MS coupled with a HPLC system (Series 200, Perkin Elmer Inc., Shelton, CT) as described in Reuter et al. [29]. The detection limit was $0.001 \mathrm{mg} / \mathrm{L}$. To note that we only observed $\mathrm{As}(\mathrm{III})$ and $\mathrm{As}(\mathrm{V})$ including some unquantifiable peaks in the chromatograms.

Analytical accuracy was checked with reference materials, and precision was ensured through repeated measurements of unknown samples. Standard reference materials (SRM 3103a and 
Table 1

Physico-chemical characteristics of the deep geothermal wells (DW) and hot spring (S) fluids in western Turkey.

\begin{tabular}{|c|c|c|c|c|c|c|c|c|c|c|c|c|c|c|c|c|c|c|c|c|}
\hline $\begin{array}{l}\text { Sample } \\
\text { ID }\end{array}$ & $\begin{array}{l}\text { Longitude (in } \\
\text { decimal } \\
\text { degrees, } \\
\text { WGS84) }\end{array}$ & $\begin{array}{l}\text { Latitude (in } \\
\text { decimal } \\
\text { degrees, } \\
\text { WGS84) }\end{array}$ & Type & Location & Depth (m) & $\begin{array}{l}\text { Temp. } \\
\left({ }^{\circ} \mathrm{C}\right)\end{array}$ & $\mathrm{pH}$ & Eh $(m V)$ & $\begin{array}{l}\text { EC } \\
(\mu S / \mathrm{cm})\end{array}$ & $\begin{array}{l}\text { DOC } \\
(\mathrm{mg} / \mathrm{L})\end{array}$ & $\mathrm{DO}(\mathrm{ppm})$ & $\begin{array}{l}\begin{array}{l}\mathrm{Na}^{+} \\
(\mathrm{mg} / \mathrm{L})\end{array} \\
\end{array}$ & $\begin{array}{l}\mathrm{Ca}^{2+} \\
(\mathrm{mg} / \mathrm{L})\end{array}$ & $\begin{array}{l}\mathrm{Mg}^{2+} \\
(\mathrm{mg} / \mathrm{L})\end{array}$ & $\begin{array}{l}\mathrm{K}^{+} \\
(\mathrm{mg} / \mathrm{L})\end{array}$ & $\begin{array}{l}\mathrm{SO}_{4}^{2-} \\
(\mathrm{mg} / \mathrm{L})\end{array}$ & $\begin{array}{l}\mathrm{Cl}^{-} \\
(\mathrm{mg} / \mathrm{L})\end{array}$ & $\begin{array}{l}\mathrm{NO}_{3}^{-} \\
(\mathrm{mg} / \mathrm{L})\end{array}$ & $\mathrm{F}^{-}(\mathrm{mg} / \mathrm{L})$ & $\begin{array}{l}\mathrm{HCO}_{3} \\
(\mathrm{mg} / \mathrm{L})\end{array}$ \\
\hline P1 & 26.910 & 38.123 & $\mathrm{~s}$ & Seferihisar & Surface & 57 & 6.45 & -13 & 3330 & 3.70 & bdl & 6094 & 1088 & 598 & 889 & 55 & 3729 & 16.9 & bdl & 469 \\
\hline P2 & 27.626 & 37.933 & s & Alangülü & Surface & 38 & 6.85 & -12 & 6920 & 4.79 & 0.06 & 1381 & 130 & 29 & 92 & 43 & 479 & 5.12 & 1.3 & 4400 \\
\hline P3 & 27.625 & 37.933 & DW & Alangülü & 47 & 39 & 7.29 & 95 & 6030 & 5.05 & 0.18 & 1124 & 159 & 65 & 100 & 6.3 & 387 & 3.42 & 1.1 & 3575 \\
\hline P4 & 27.583 & 37.886 & DW & Hidırbeyli & 1900 & 130 & 8.30 & 32 & 6900 & 4.53 & 0.68 & 1467 & 11 & 16 & 98 & 14 & 598 & 4.76 & 1.7 & 3025 \\
\hline P5 & 28.099 & 37.880 & DW & Salavatli & 1510 & 171 & 7.69 & -222 & 4970 & 3.50 & 0.93 & 1152 & 18 & 13 & 96 & 63 & 111 & 2.31 & 6.2 & 3090 \\
\hline P6 & 28.095 & 37.876 & DW & Salavatli & 1450 & 170 & 7.58 & -250 & 4820 & 2.86 & 0.62 & 1134 & 11 & 15 & 90 & 63 & 112 & 3.19 & 8.1 & 3100 \\
\hline P7 & 28.829 & 37.921 & DW & Sarayköy & 300 & 120 & 8.77 & -160 & 3890 & 3.36 & 0.77 & 841 & 105 & 18 & 103 & 497 & 39 & 3.51 & 4.9 & 1955 \\
\hline P8 & 28.828 & 37.921 & $\mathrm{~s}$ & Sarayköy & Surface & 40 & 6.62 & 16 & 5450 & 3.48 & 0.24 & 892 & 333 & 112 & 92 & 993 & 81 & 3.71 & 5.3 & 3460 \\
\hline P9 & 28.808 & 37.927 & $\mathrm{~s}$ & $\begin{array}{l}\text { Buharkent } \\
\text { (inalt1) }\end{array}$ & Surface & 90 & 8.67 & 40 & 4360 & 3.81 & 0.68 & 953 & 22 & 15 & 94 & 870 & 43 & 3.53 & 6.3 & 1510 \\
\hline P10 & 28.774 & 37.933 & $\mathrm{~s}$ & $\begin{array}{l}\text { Buharkent } \\
\text { (Babacklk) }\end{array}$ & Surface & 60 & 6.67 & -213 & 3610 & 3.38 & 0.76 & 523 & 405 & 95 & 51 & 767 & 30 & 4.04 & 2.2 & 2725 \\
\hline P11 & 28.846 & 37.960 & DW & Kizldere & 510 & 193 & 8.57 & -148 & 4070 & 1.09 & 0.48 & 1181 & 12 & 12 & 131 & 459 & 52 & 3.73 & 11 & 1907 \\
\hline P12 & 28.837 & 37.952 & DW & Kizıldere & 2250 & 190 & 8.13 & -48 & 4720 & 2.06 & 0.88 & 1135 & 34 & 10 & 89 & 469 & 59 & 2.09 & 4.8 & 2306 \\
\hline P13 & 29.103 & 37.968 & $\mathrm{~s}$ & Karahayit & Surface & 40 & 6.59 & 13 & 2850 & 3.66 & 0.92 & 123 & 693 & 115 & 27 & 523 & 15 & 5.23 & 1.0 & 1964 \\
\hline P14 & 29.108 & 37.962 & DW & Karahayit & 150 & 58 & 6.72 & 24 & 3010 & 3.21 & 0.73 & 110 & 657 & 109 & 25 & 507 & 13 & 3.15 & 1.1 & 2130 \\
\hline P15 & 29.126 & 37.926 & s & Pamukkale & Surface & 33 & 6.41 & 107 & 2520 & 3.41 & 0.84 & 45 & 736 & 97 & 7.9 & 391 & 8.0 & 3.43 & 0.60 & 2159 \\
\hline P16 & 28.747 & 38.650 & s & Kula & Surface & 60 & 7.06 & -63 & 4480 & 2.82 & 0.04 & 936 & 67 & 91 & 92 & 62 & 96 & 1.92 & 0.80 & 3550 \\
\hline P17 & 28.747 & 38.650 & DW & Kula & 163 & 65 & 7.14 & 11 & 4270 & 3.34 & 0.45 & 966 & 150 & 101 & 95 & 61 & 99 & 4.45 & 0.80 & 3900 \\
\hline P18 & 28.960 & 39.142 & DW & Naşa & $\mathrm{N} / \mathrm{A}$ & 85 & 7.61 & 109 & 1621 & 3.77 & 0.96 & 292 & 100 & 12 & 33 & 158 & 23 & 3.55 & 2.2 & 886 \\
\hline P19 & 28.966 & 39.134 & DW & Çitgöl & $\mathrm{N} / \mathrm{A}$ & 95 & 7.62 & 109 & 1757 & 3.12 & 0.28 & 150 & 12 & 16 & 3.2 & 193 & 25 & 3.78 & 4.0 & 325 \\
\hline P20 & 28.995 & 39.127 & DW & Eynal & $\mathrm{N} / \mathrm{A}$ & 160 & 9.30 & -62 & 2940 & 1.71 & 0.20 & 659 & 21 & 11 & 77 & 332 & 43 & 3.42 & 11 & 1244 \\
\hline P21 & 29.257 & 38.940 & DW & Gediz & $\mathrm{N} / \mathrm{A}$ & 85 & 7.15 & 94 & 3410 & 3.35 & 0.20 & 568 & 211 & 67 & 85 & 574 & 50 & 4.32 & 2.0 & 2035 \\
\hline P22 & 29.256 & 38.940 & $\mathrm{~s}$ & Gediz & Surface & 75 & 7.09 & 119 & 2990 & 2.90 & 0.86 & 465 & 222 & 78 & 70 & 490 & 43 & 4.12 & 1.6 & 1975 \\
\hline P23 & 29.189 & 38.745 & s & Emirfak1 & Surface & 39 & 6.56 & 39 & 2690 & 3.39 & 0.55 & 278 & 466 & 88 & 38 & 467 & 23 & 2.16 & 0.70 & 2605 \\
\hline P24 & 29.052 & 38.639 & DW & Örencik & $\mathrm{N} / \mathrm{A}$ & 39 & 6.89 & 75 & 4120 & 4.34 & 0.06 & 831 & 255 & 71 & 91 & 176 & 38 & 3.14 & 0.40 & 3950 \\
\hline P25 & 28.521 & 38.332 & $\mathrm{~s}$ & Alaşehir & Surface & 32 & 6.62 & 93 & 2460 & 4.07 & 0.13 & 245 & 248 & 141 & 17 & 106 & 32 & 2.51 & 0.20 & 2265 \\
\hline P26 & 28.368 & 38.407 & DW & Kavaklıdere & $\mathrm{N} / \mathrm{A}$ & 213 & 6.98 & -47 & 3210 & 3.21 & 0.70 & 727 & 17 & 11 & 79 & 10 & 89 & 4.53 & 1.4 & 2405 \\
\hline P27 & 28.115 & 38.451 & DW & Salihli & $\mathrm{N} / \mathrm{A}$ & 84 & 7.66 & -85 & 2340 & 3.72 & 0.97 & 433 & 126 & 22 & 56 & 29 & 39 & 3.78 & 1.0 & 1830 \\
\hline P28 & 28.082 & 38.512 & DW & Bostan-Salihli & 1100 & 80 & 7.78 & -20 & 2114 & 3.96 & 0.88 & 527 & 13 & 14 & 11 & 27 & 45 & 3.73 & 0.20 & 1405 \\
\hline P29 & 28.048 & 38.456 & $\mathrm{~s}$ & Sart & Surface & 52 & 6.59 & -101 & 1575 & 2.85 & 0.78 & 148 & 289 & 35 & 22 & 29 & 15 & 4.06 & 0.40 & 1793 \\
\hline P30 & 27.840 & 38.571 & DW & Urganlı & 400 & 80 & 7.32 & -75 & 2380 & 3.36 & bdl & 495 & 56 & 33 & 52 & 2.3 & 38 & 2.16 & 2.3 & 1500 \\
\hline P31 & 27.035 & 38.387 & DW & Balçova & 371 & 102 & 7.68 & -53 & 1823 & 3.25 & 0.82 & 348 & 55 & 15 & 32 & 84 & 89 & 1.38 & 3.3 & 1210 \\
\hline
\end{tabular}

DW - deep geothermal wells; $\mathrm{S}$ - hot springs; N/A - not available; bdl - below detection limit. 


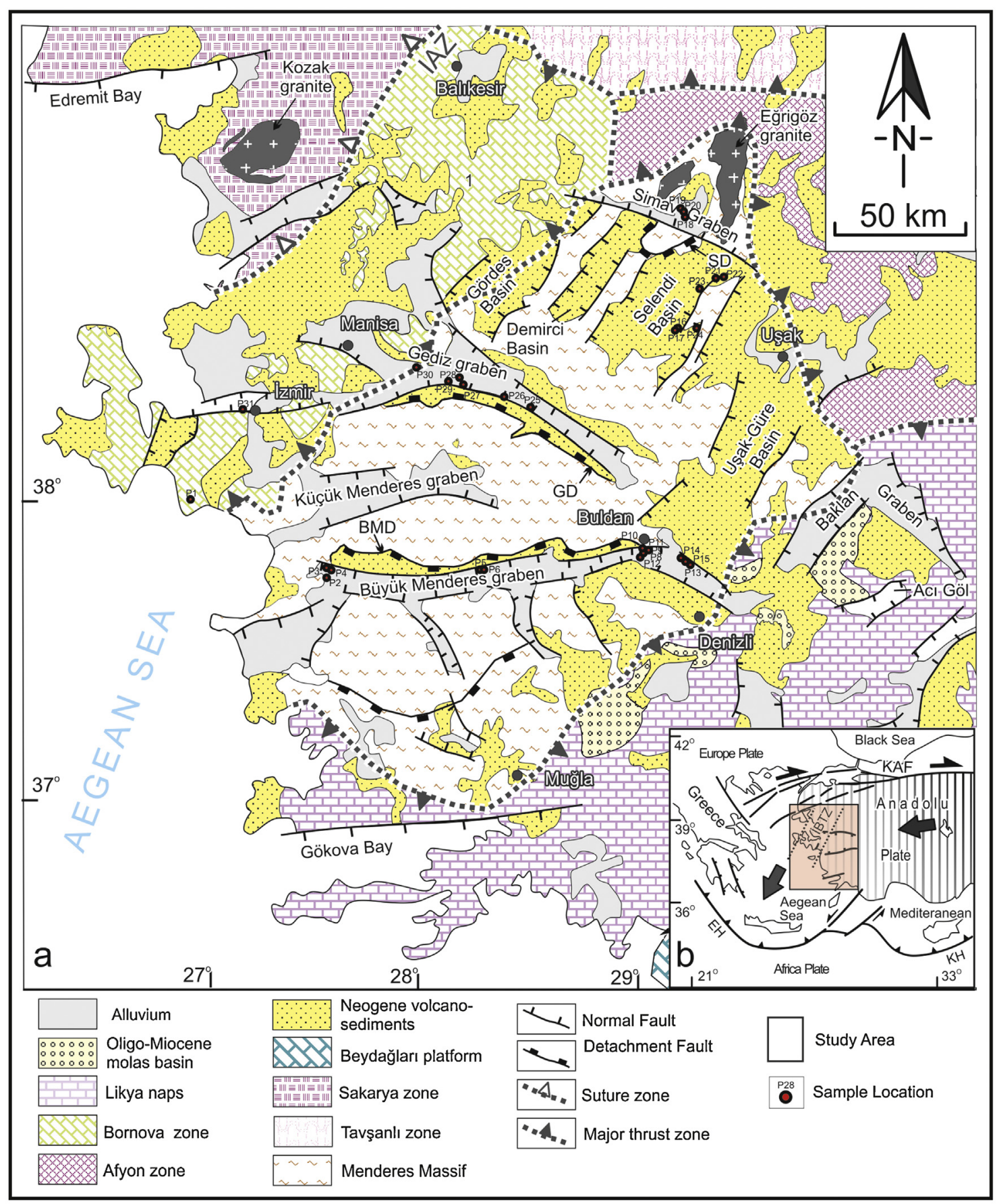

Fig. 1. Geological map of western Turkey (modified after Sözbilir et al. [40] and MTA [41]). The map also shows the location of sampling points and geothermal inventory.

1640a) from the National Institute of Standards and Technology (NIST) were used to achieve analytical accuracy. The detection limit for As and other analyzed trace element was $0.001 \mathrm{mg} / \mathrm{L}$. The coefficient of variation (CV) was calculated to test the reliability of the data and was found to be $<5 \%$ in all replicates.

\subsection{Statistical analysis}

Correlation statistics and the level of statistical significance were analyzed using statistical software SPSS 13.0 [30]. A $p$ value $<0.05$ was considered to indicate the level of statistical significance.
Linear regression was used to observe the correlation of As with other elements.

\section{Results and discussion}

\subsection{Physico-chemical characteristics of geothermal waters - deep wells and hot springs}

The measured physico-chemical characteristics of geothermal waters are presented in Table 1 . The measured temperature of geothermal waters in deep wells ranged between 39 and $213^{\circ} \mathrm{C}$ with a median of $95^{\circ} \mathrm{C}$, whereas it was below the boiling point for 


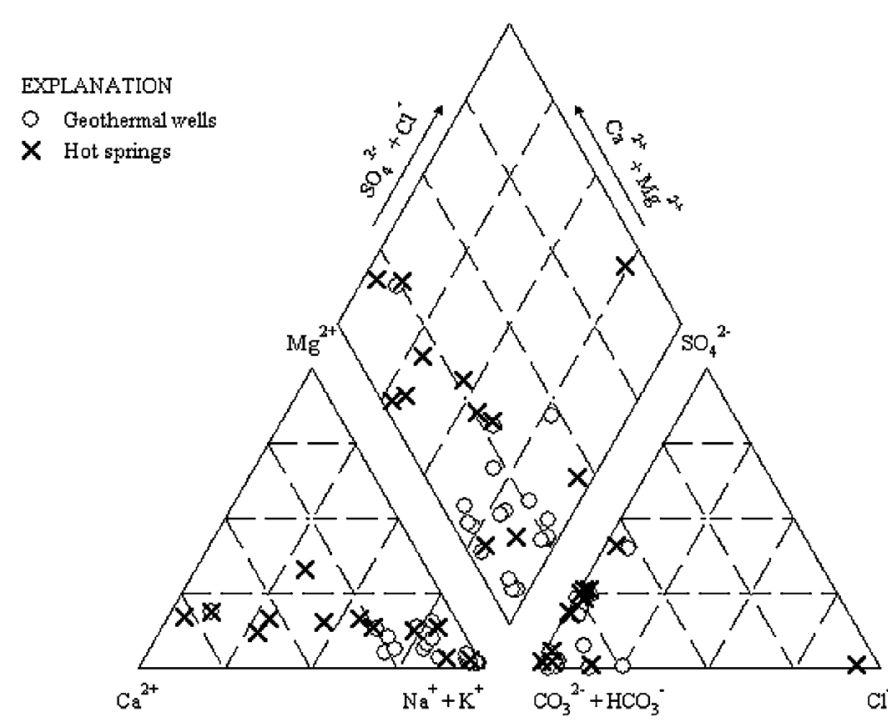

Fig. 2. Piper diagram illustrating major water types of geothermal wells and hot spring fluids of the study area.

hot spring fluids, ranged between 32 and $90^{\circ} \mathrm{C}$ (median: $46^{\circ} \mathrm{C}$ ). The $\mathrm{pH}$ of geothermal waters in deep wells was slightly alkaline with a median of 7.6, whereas it was mostly neutral for hot spring fluids with a median of 6.6. The electrical conductivity ranged between 1621 and $6900 \mu \mathrm{S} / \mathrm{cm}$ (median: $3410 \mu \mathrm{S} / \mathrm{cm}$ ) in geothermal waters in deep wells. The hot spring fluids also show similar EC values with a median of $3160 \mu \mathrm{S} / \mathrm{cm}$ (range: $1575-6920 \mu \mathrm{S} / \mathrm{cm}$ ).

The Piper plot (Fig. 2) illustrates dominant hydrochemical features of geothermal waters in deep wells and hot springs in the study area. The geothermal waters in deep wells showed enriched concentration of $\mathrm{Na}^{+}$(median: $727 \mathrm{mg} / \mathrm{L}$ ) relative to $\mathrm{Ca}^{2+}$ (median: $55 \mathrm{mg} / \mathrm{L}$ ), whereas hot spring fluids showed enriched concentration of $\mathrm{Ca}^{2+}$ (median: $311 \mathrm{mg} / \mathrm{L}$ ). The $\mathrm{Ca}^{2+}$ concentrations in hot spring fluids ranged between 22 and $1088 \mathrm{mg} / \mathrm{L}$. However, $\mathrm{Ca}^{2+}$ concentrations were generally low, ranged between 1.9 and $657 \mathrm{mg} / \mathrm{L}$ in geothermal waters in deep wells. Geothermal waters in deep wells are of the $\mathrm{Na}-\mathrm{HCO}_{3}-$ type, whereas hot spring fluids are mostly of the $\mathrm{Ca}-\mathrm{HCO}_{3}{ }^{-}$type (Fig. 2). The Seferihisar hot spring exhibited a $\mathrm{Na}-\mathrm{Cl}$ type with high concentrations of $\mathrm{Na}^{+}(6094 \mathrm{mg} / \mathrm{L})$ and $\mathrm{Cl}^{-}$ (3729 mg/L) compared with other hot spring fluids and geothermal waters in deep wells of the studied region (Table 1). This is perhaps due to mixing and/or intrusion of seawater with rising geothermal waters. The $\mathrm{SO}_{4}{ }^{2-}$ concentrations ranged between 2.3 and $574 \mathrm{mg} / \mathrm{L}$ (median: $84 \mathrm{mg} / \mathrm{L}$ ) in geothermal deep wells, whereas slightly higher concentrations of $\mathrm{SO}_{4}{ }^{2-}$ was observed in hot spring fluids (range: 29-993, median: $429 \mathrm{mg} / \mathrm{L}$ ).

\subsection{Arsenic species in geothermal waters - deep wells and hot springs}

Table 2 shows measured concentrations of As, As(III) and As(V) in geothermal waters at each study locations. Table 2 also shows some unknown As species which was calculated as the difference between total As concentrations and sum of reported inorganic As species. Overall, the data showed As(III) as the dominant species in most of the samples. The reported unknown As species potentially represents As-sulfide (thioarsenic) species that could not be quantifiable using our method. However, Planar-Friedrich et al. [31] were able to quantify mono-, di-, tri-, and tetra-thioarsenate, as well as methylated As oxy- and thio-anions, besides $\mathrm{As}(\mathrm{III})$ and $\mathrm{As}(\mathrm{V})$ in geothermal waters of Yellowstone National Park. Therefore, our future work is directed to investigate the nature and occurrence of these unknown As species in the study area and their importance on As biogeochemical processes.

In geothermal waters, As occurs mostly in inorganic forms, either as $\mathrm{As}(\mathrm{III})$ or $\mathrm{As}(\mathrm{V})$. Geothermal waters that emerged to the Earth's surface predominantly contain $\mathrm{As}(\mathrm{V})$ species. However, in deep geothermal reservoirs, As(III) is dominant, although, the dissolved inorganic As may changes its oxidation states depending on the reservoir thermodynamic condition [2]. Generally, As(III) slowly oxidized to $\mathrm{As}(\mathrm{V})$ during the rise of geothermal waters from deep sources due to gradual increase in contact with atmospheric oxygen. The rate of As oxidation can be accelerated in the presence of microorganisms. For example, Wilkie and Hering [32] observed decrease in dissolved As(III) concentrations starting from the geothermal spring vent to $1.2 \mathrm{~km}$ downstream along with increase in $\mathrm{As}(\mathrm{V})$ concentrations, where stream macrophytes provided required microbial loads. Cumbal et al. [33] observed the dominance of $\mathrm{As}$ (III) (61-74\% of the total As) in hot spring fluids characterized by low redox potential (Eh: -112 and $-104 \mathrm{mV}$ ), whereas, $\mathrm{As}(\mathrm{V})$ dominance (67-68\% of the total As) in hot spring fluids was characterized by higher redox potential (Eh: 9.2 and $7.3 \mathrm{mV}$ ). We also observed similar relation between As species and Eh values, for example, negative Eh values correspond to the dominance of As(III) whereas positive Eh values correspond to the dominance of $\operatorname{As}(\mathrm{V})$ in geothermal waters in deep wells and hot springs (Table 1 ).

\subsection{Geochemical behavior of geothermal waters - deep wells and hot springs}

The majority of trace elements found in the studied geothermal waters were above the World Health Organization (WHO) guidelines [34] and the national safe drinking water limits of Turkey. Arsenic concentrations were highly variable, and were mostly above the WHO drinking water guidelines $(0.01 \mathrm{mg} / \mathrm{L})$. Arsenic concentration in geothermal deep wells were found in the range of 0.03-1.1 mg/L (median: $0.26 \mathrm{mg} / \mathrm{L}$ ), whereas in hot spring fluids, it ranged between 0.06 and $1.5 \mathrm{mg} / \mathrm{L}$ (median: $0.18 \mathrm{mg} / \mathrm{L}$ ). The highest As concentration was found in the Buharkent (İnaltı) hot spring and Kizıldere geothermal deep wells, with values of 1.5 and $1.1 \mathrm{mg} / \mathrm{L}$, respectively. A strong positive correlation $\left(r^{2}=0.67\right)$ was observed between As and Fe in geothermal waters in deep wells, whereas no correlation was observed in hot spring fluids (Fig. 3a). Similarly As and DOC have a strong negative correlation in geothermal waters in deep wells but no correlation was observed in hot spring fluids (Fig. 3b). The correlation between As and Mn was not significant (Fig. 3c).

We observed a good correlation between $\mathrm{pH}$ and As concentrations in geothermal waters in deep wells and hot springs with $r^{2}$ values of 0.50 and 0.81 , respectively (Fig. 4a). Positive correlation was also observed for As(III) concentrations with measured $\mathrm{pH}$ in geothermal waters in deep wells and hot springs (Fig. 4b). Hot spring fluids also show a positive relationship between $\mathrm{As}(\mathrm{V})$ and $\mathrm{pH}$ but not with geothermal waters in deep wells (Fig. 4c). In general, $\mathrm{pH}$ and solubility of dissolved chemical constituents in geothermal waters often affected by the loss of $\mathrm{CO}_{2}$ during adiabatic cooling of the ascending geothermal fluids [2]. However, As and other elements, such as $\mathrm{Au}, \mathrm{Sb}$ and $\mathrm{Hg}$, may remain dissolved under alkaline $\mathrm{pH}$. Upon atmospheric contact, i.e., near the Earth's surface, the dissolved redox sensitive elements may precipitate or changes its oxidation states. This is mainly due to the dominance of reducing condition along the pathways of ascending geothermal waters, however, oxidizing condition were dominant at or near the Earth's surface, due to availability of atmospheric $\mathrm{O}_{2}$. The exposure of geothermal waters to Earth's surface results in the oxidation of $\mathrm{As}(\mathrm{III})$ to $\mathrm{As}(\mathrm{V})$ and the precipitation of redox sensitive mineral phases such as Fe-oxides [35], which subsequently 
Table 2

Arsenic species and trace element composition of the deep geothermal wells (DW) and hot spring (S) fluids in western Turkey.

\begin{tabular}{|c|c|c|c|c|c|c|c|c|c|c|c|c|c|c|c|c|c|c|c|c|}
\hline $\begin{array}{l}\text { Sampling } \\
\text { ID }\end{array}$ & Type & $\mathrm{As}(\mathrm{mg} / \mathrm{L})$ & $\begin{array}{l}\text { As (III) } \\
(\mathrm{mg} / \mathrm{L})\end{array}$ & $\begin{array}{l}\text { As }(\mathrm{V}) \\
(\mathrm{mg} / \mathrm{L})\end{array}$ & $\begin{array}{l}\text { Unknown } \\
\text { As (mg/L) }\end{array}$ & $\mathrm{Fe}(\mathrm{mg} / \mathrm{L})$ & $\mathrm{Mn}(\mathrm{mg} / \mathrm{L})$ & $\mathrm{Al}(\mathrm{mg} / \mathrm{L})$ & $\mathrm{B}(\mathrm{mg} / \mathrm{L})$ & $\mathrm{Rb}(\mathrm{mg} / \mathrm{L})$ & $\mathrm{Ba}(\mathrm{mg} / \mathrm{L})$ & $\operatorname{Sr}(\mathrm{mg} / \mathrm{L})$ & $\mathrm{Br}(\mathrm{mg} / \mathrm{L})$ & $\mathrm{Cr}(\mathrm{mg} / \mathrm{L})$ & $\mathrm{Ni}(\mathrm{mg} / \mathrm{L})$ & $\mathrm{Zn}(\mathrm{mg} / \mathrm{L})$ & $\mathrm{Se}(\mathrm{mg} / \mathrm{L})$ & $\mathrm{Sb}(\mathrm{mg} / \mathrm{L})$ & $\mathrm{Ge}(\mathrm{mg} / \mathrm{L})$ & $\mathrm{Cs}(\mathrm{mg} / \mathrm{L})$ \\
\hline P1 & $\mathrm{S}$ & 0.21 & 0.03 & 0.09 & 0.09 & 0.24 & 0.19 & bdl & 0.01 & bdl & 0.05 & bdl & bdl & 0.02 & 0.12 & 0.02 & bdl & 0.001 & 0.001 & 0.15 \\
\hline P2 & s & 0.19 & 0.08 & 0.04 & 0.07 & 0.14 & 0.12 & bdl & 0.01 & bdl & 0.03 & bdl & bdl & bdl & bdl & 0.09 & bdl & bdl & 0.005 & 0.05 \\
\hline P3 & DW & 0.08 & bdl & 0.02 & 0.06 & 0.05 & 0.01 & 0.42 & 0.72 & 0.24 & 0.30 & 0.62 & 3.34 & bdl & 0.13 & 0.11 & 0.008 & bdl & 0.006 & 0.04 \\
\hline P4 & DW & 0.15 & 0.08 & 0.03 & 0.04 & 0.12 & 0.01 & 0.06 & 2.91 & 0.03 & 0.08 & 0.11 & 0.98 & 0.03 & 0.26 & 0.05 & 0.002 & 0.028 & 0.009 & 0.06 \\
\hline P5 & DW & 0.29 & 0.11 & 0.03 & 0.15 & 0.57 & bdl & 0.05 & 2.68 & 0.04 & 0.02 & 0.18 & 0.99 & 0.03 & 0.27 & 0.11 & 0.001 & 0.009 & 0.006 & 0.04 \\
\hline P6 & DW & 0.29 & 0.03 & 0.03 & 0.23 & 0.26 & 0.01 & 0.08 & 3.79 & 0.04 & 0.03 & 0.15 & 1.36 & 0.02 & 0.18 & 0.15 & 0.009 & 0.004 & 0.006 & 0.04 \\
\hline P7 & DW & 0.60 & 0.43 & 0.04 & 0.13 & 0.13 & 0.01 & 0.08 & 3.51 & 0.02 & bdl & 0.07 & 0.64 & 0.03 & 0.09 & 0.02 & bdl & 0.009 & 0.003 & 0.02 \\
\hline P8 & s & 0.43 & 0.26 & 0.04 & 0.13 & 0.41 & 0.09 & 0.11 & 4.05 & 0.02 & 0.01 & 0.06 & 1.04 & bdl & 0.06 & 0.03 & bdl & 0.003 & 0.002 & 0.02 \\
\hline P9 & s & 1.50 & 1.0 & 0.14 & 0.36 & 0.56 & bdl & 0.07 & 1.05 & 0.03 & bdl & 0.31 & 0.80 & bdl & 0.12 & 0.05 & bdl & 0.018 & 0.003 & 0.01 \\
\hline P10 & $\mathrm{s}$ & 0.16 & 0.04 & 0.02 & 0.10 & 0.29 & 0.09 & 0.08 & 0.92 & 0.03 & bdl & 0.48 & 0.67 & bdl & bdl & bdl & bdl & bdl & bdl & bdl \\
\hline P11 & DW & 1.13 & 0.89 & 0.12 & 0.12 & 1.25 & bdl & 0.08 & 1.27 & 0.03 & 0.01 & 0.28 & 0.73 & 0.01 & bdl & 0.06 & bdl & 0.015 & 0.004 & 0.02 \\
\hline P12 & DW & 1.08 & 0.87 & 0.11 & 0.10 & 1.45 & bdl & bdl & 3.78 & bdl & bdl & bdl & bdl & 0.01 & bdl & 0.05 & bdl & 0.005 & 0.003 & 0.01 \\
\hline P13 & S & 0.13 & 0.04 & 0.02 & 0.07 & 0.59 & 0.04 & 0.09 & 1.28 & 0.04 & bdl & 0.09 & 0.33 & 0.02 & 0.23 & 0.05 & bdl & bdl & bdl & bdl \\
\hline P14 & DW & 0.13 & 0.02 & 0.01 & 0.10 & 0.19 & 0.03 & 0.08 & 0.86 & 0.02 & bdl & 0.12 & 0.42 & 0.01 & bdl & 0.07 & bdl & bdl & bdl & bdl \\
\hline P15 & S & 0.12 & bdl & 0.01 & 0.11 & 0.29 & 0.01 & 0.03 & 0.12 & 0.01 & bdl & 0.46 & 0.37 & 0.02 & 0.24 & 0.12 & bdl & bdl & bdl & bdl \\
\hline P16 & S & 0.09 & bdl & bdl & 0.09 & 0.15 & bdl & 0.03 & 0.09 & 0.01 & 0.02 & 0.43 & 0.28 & bdl & bdl & 0.05 & bdl & bdl & 0.002 & 0.01 \\
\hline P17 & DW & 0.03 & bdl & bdl & 0.03 & 0.13 & 0.03 & 0.05 & 0.05 & bdl & 0.02 & 0.32 & 0.42 & bdl & 0.09 & 0.01 & bdl & bdl & 0.001 & 0.01 \\
\hline P18 & DW & 0.42 & 0.02 & 0.24 & 0.16 & 0.24 & 0.23 & 0.06 & 0.38 & 0.02 & 0.01 & 0.11 & 0.47 & bdl & 0.06 & 0.02 & bdl & 0.003 & 0.002 & 0.01 \\
\hline P19 & DW & 0.38 & bdl & 0.22 & 0.16 & 0.51 & 0.09 & 0.06 & 0.38 & 0.03 & 0.01 & 0.15 & 0.50 & bdl & bdl & 0.01 & bdl & 0.002 & 0.002 & 0.01 \\
\hline P20 & DW & 0.71 & 0.23 & 0.07 & 0.41 & 0.85 & 0.01 & 0.04 & 0.15 & 0.01 & 0.01 & 0.05 & 0.27 & bdl & bdl & 0.04 & bdl & 0.002 & 0.002 & 0.02 \\
\hline P21 & DW & 0.21 & 0.09 & 0.06 & 0.06 & 0.35 & 0.02 & 0.05 & 0.21 & 0.02 & bdl & 0.03 & 0.48 & 0.01 & 0.23 & 0.01 & bdl & bdl & 0.001 & 0.01 \\
\hline P22 & S & 0.24 & bdl & 0.15 & 0.09 & 0.46 & 0.08 & 0.05 & 0.31 & 0.03 & bdl & 0.03 & 0.28 & 0.01 & 0.26 & 0.01 & bdl & bdl & 0.001 & 0.01 \\
\hline P23 & S & 0.29 & 0.11 & 0.04 & 0.14 & 0.81 & 0.02 & 0.03 & 0.26 & 0.02 & bdl & 0.17 & 0.27 & 0.01 & 0.02 & 0.01 & bdl & bdl & bdl & bdl \\
\hline P24 & DW & 0.08 & 0.03 & 0.02 & 0.03 & 0.25 & 0.02 & 0.04 & 0.24 & 0.02 & bdl & 0.17 & 0.28 & bdl & bdl & 0.01 & bdl & bdl & 0.001 & 0.01 \\
\hline P25 & S & 0.06 & 0.02 & 0.01 & 0.03 & 0.35 & 0.08 & 0.03 & 0.07 & 0.01 & 0.01 & 0.21 & 0.25 & 0.01 & 0.01 & 0.01 & bdl & 0.005 & 0.001 & 0.01 \\
\hline P26 & DW & 0.18 & 0.10 & 0.02 & 0.06 & 0.39 & 0.04 & 0.03 & 0.15 & 0.02 & 0.07 & 0.20 & 0.39 & bdl & bdl & 0.02 & bdl & bdl & 0.007 & 0.03 \\
\hline P27 & DW & 0.35 & 0.27 & 0.04 & 0.04 & 0.67 & 0.01 & 0.03 & 0.78 & bdl & 0.01 & 0.06 & 0.36 & bdl & bdl & 0.02 & bdl & 0.001 & 0.004 & 0.03 \\
\hline P28 & DW & 0.18 & 0.06 & 0.08 & 0.04 & 0.31 & 0.01 & 0.06 & 4.04 & 0.03 & 0.01 & 0.02 & 0.48 & bdl & bdl & 0.03 & bdl & 0.001 & 0.001 & bdl \\
\hline P29 & S & 0.09 & 0.06 & 0.02 & 0.01 & 0.21 & 0.15 & 0.06 & 2.01 & 0.02 & 0.01 & 0.06 & 0.61 & bdl & bdl & 0.03 & Bdl & bdl & 0.001 & 0.01 \\
\hline P30 & DW & 0.09 & bdl & 0.01 & 0.08 & 0.37 & 0.01 & 0.06 & 1.02 & bdl & 0.07 & 0.02 & 0.54 & bdl & 0.01 & 0.03 & bdl & bdl & 0.002 & 0.01 \\
\hline P31 & DW & 0.26 & 0.11 & 0.05 & 0.10 & 0.86 & 0.04 & 0.05 & 0.52 & 0.01 & 0.01 & 0.06 & 0.47 & 0.01 & bdl & 0.04 & bdl & 0.008 & 0.001 & 0.02 \\
\hline
\end{tabular}

DW - deep geothermal wells; $\mathrm{S}$ - hot springs; bdl - below detection limit. 

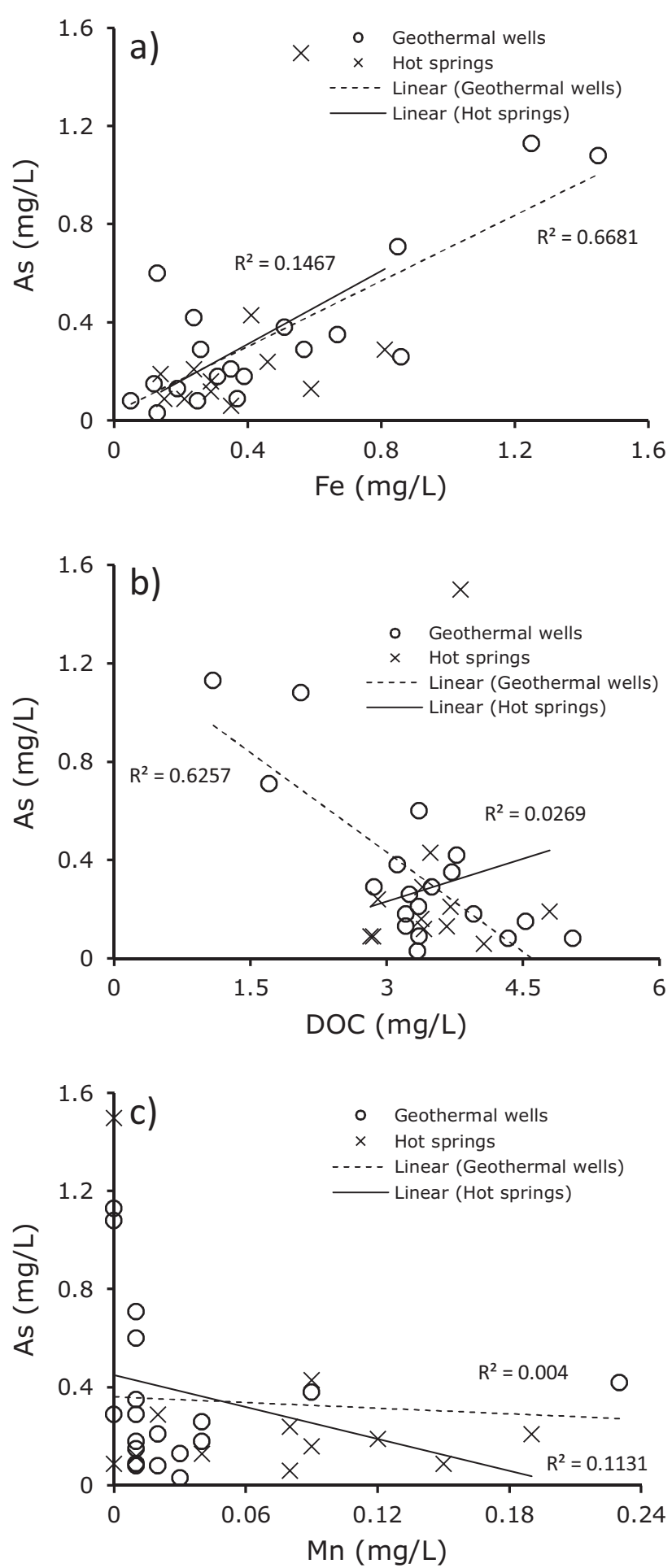

Fig. 3. Correlation between (a) As vs. Fe, (b) As vs. DOC and (c) As vs. Mn in geothermal wells and hot spring fluids of the study area.

sequester As from the water to variable extents. The sorption of As onto Fe oxyhydroxides is especially dominant in near-neutral $\mathrm{pH}$ and $\mathrm{Na}-\mathrm{Cl}-\mathrm{HCO}_{3}{ }^{-}$type waters $[2,35]$ and thus controls As mobility. Such behavior of geothermal waters largely controls the relationship between $\mathrm{pH}$ and As species in the studied area (Fig. $4 \mathrm{~b}$ and $\mathrm{c}$ ).

Typically, geothermal waters contained elevated levels of B. In deep geothermal wells, $\mathrm{B}$ concentrations were found in the range between 0.05 and $4.0 \mathrm{mg} / \mathrm{L}$ (median: $0.78 \mathrm{mg} / \mathrm{L}$ ), whereas, it was in the range between 0.01 and $4.05 \mathrm{mg} / \mathrm{L}$ (median: $0.29 \mathrm{mg} / \mathrm{L}$ ) in hot spring fluids. The molar ratios of $\mathrm{Cl} / \mathrm{B}$ in high temperature
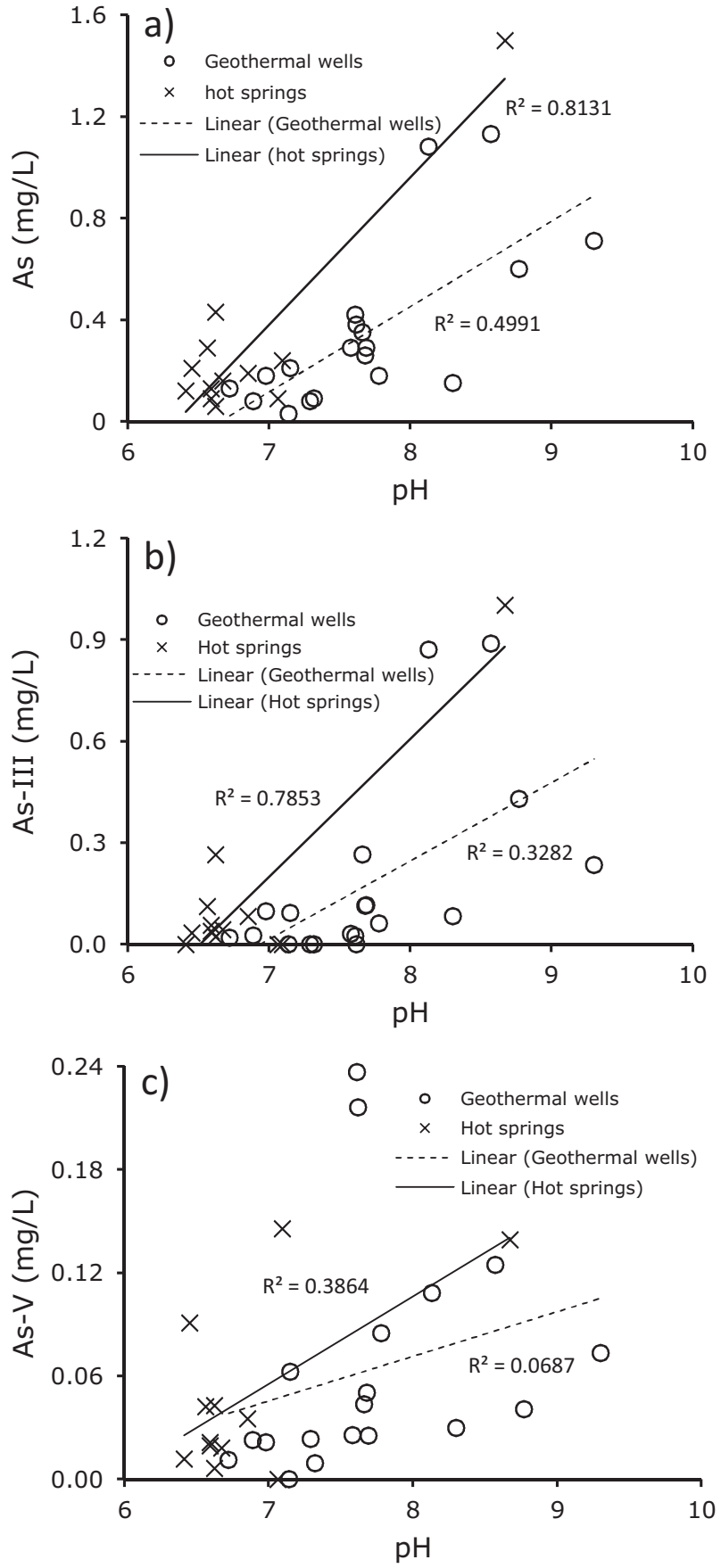

Fig. 4. Correlation between (a) As vs. $\mathrm{pH}$, (b) $\mathrm{As}(\mathrm{III})$ vs. $\mathrm{pH}$ and (c) $\mathrm{As}(\mathrm{V}) \mathrm{vs}$. $\mathrm{pH}$ in geothermal wells and hot spring fluids of the study area.

$\left(>150^{\circ} \mathrm{C}\right)$ fluids were low compared to low temperature fluids $\left(<150^{\circ} \mathrm{C}\right)$. Additionally in some geothermal waters in deep wells and hot spring fluids high concentrations of Sb (up to 0.028 and $0.018 \mathrm{mg} / \mathrm{L}$, respectively) were observed. We observed no correlation between $\mathrm{As}$ and $\mathrm{Sb}$ in geothermal waters which suggests their co-occurrence. In addition to As, $\mathrm{Sb}$ is highly carcinogenic above the permissible drinking water limit of WHO $(0.005 \mathrm{mg} / \mathrm{L})$.

\section{Potential consequences for contamination of local freshwater resources}

The rising geothermal waters generally discharged into Earth's surface as a hot spring or mixed with shallow "cold" groundwater. 
Either of these may result in contamination of groundwater and surface water with contaminants such as As $[18,19]$. The contamination of groundwater and/or surface water can occur additionally through geothermal energy exploitation if residual wastewaters are not adequately re-injected deep underground; this may result in severe environmental impact of contamination of freshwater resources used for drinking and irrigation [18,21,36]. Baba et al. [37] suggested two dominant behaviors which could potentially affecting the shallow groundwater quality in Tuzla geothermal region: (i) influx of salts and trace elements with geothermal brines during different seasons, and (ii) mixing of geothermal waters with shallow groundwater through fractures. Aksoy et al. [38] observed that the mixing of geothermal waters with "cold" shallow aquifers was mainly through the fractured zone, e.g. a fault line which conduit geothermal fluid. Similar observations were also reported from other parts of the world, such as an aqueduct in Los Angeles, USA, where high As concentrations (mean: $0.02 \mathrm{mg} / \mathrm{L}$ ) were sourced from the geothermal activity in the Long valley, Mono county [32]. Tyrovola et al. [39] observed gradual decrease in As concentrations from the point of mixing of geothermal waters with shallow unconfined aquifers to the coastal area, approximately $7 \mathrm{~km}$ downstream. Such variations in As concentrations may relate to stratigraphy, depth of wells and redox status of the aquifer. Cumbal et al. [33] observed contamination of groundwater in Ecuador, where the discharge of geothermal water containing high concentrations of As (1.1-7.9 $\mathrm{mg} / \mathrm{L}$ ) has lead to a severe environmental exposure.

In our study area we observed high concentrations of As, Sb and $B$ in the hot spring fluids which have a direct impact on human health through mixing with freshwater resources used for drinking and irrigation. For example, high As and Sb concentrations has carcinogenic effects to human health and potentially accumulate in agricultural produce. High B concentrations can cause human health effects. Additionally high B concentrations can have a detrimental effect to crops. Gunduz et al. [7] previously reported human health effects associated with the use of As contaminated local freshwater resources for drinking and irrigation. They also reported carcinogenic effects on people living in this region. Therefore, alternative drinking water sources need to be implemented in the study area to avoid further human health effects from drinking of As contaminated water. In addition to that proper management strategies should be adopted in order to avoid cross-contamination of fresh groundwater resources.

\section{Conclusions}

The studied geothermal waters contain higher concentrations of As, B, and other trace elements relative to WHO drinking water guidelines and the national drinking water safe limits of Turkey. The reduced $\mathrm{As}(\mathrm{III})$ is the dominant form of As found in the geothermal waters of the studied area, although some unknown As species were observed. We observed deterioration of local shallow freshwater resources through As and other trace element contamination due to mixing of geothermal waters and/or utilization of geothermal resources for energy regeneration [18,21]. Therefore, proper management and control strategy must be adopted in order to ascertain environmental safety to freshwater resources which is currently under threat from geothermal activity.

\section{Acknowledgments}

JB and PB thank the Strategic Environmental Research Foundation (Mistra) for the financial support extended to the KTH-International Groundwater Arsenic Research Group at the Department of Land and Water Resources Engineering, Royal
Institute of Technology, Stockholm, Sweden. PB also thanks the Swedish International Development Agency (Sida) for the financial support on global advocacy through the project Sustainable Arsenic Mitigation (SASMIT) (Sida Contribution 750000854) between 2007-2013. This work is partly supported by the Scientific and Technological Council of Turkey (TUBITAK) through project number 109Y029. JPM would like to thank the National Science Council of Taiwan for a postdoctoral position (NSC 100-2811-M-194-008). BN acknowledges The University of Sydney for Research Support Grant.

\section{References}

[1] D.W. Layton, L.R. Anspaugh, K.D. O’Banion, Health and Environmental Effects Document on Geothermal Energy, Prepared for: Health and Environmental Risk Analysis Program, Human Health and Assessment Division, Office of Health and Environmental Research, Office of Energy Research, U.S. Department of Energy, Lawrence Livermore Laboratory, University of California, Livermore, California, USA, 1981, pp. 1-69.

[2] J.G. Webster, D.G. Nordstrom, Geothermal arsenic, in: A.H. Welch, K.G. Stollenwerk (Eds.), Arsenic in Ground Water: Geochemistry and Occurrence, Springer, New York, USA, 2003, pp. 101-125.

[3] G. Tamasi, R. Cini, Heavy metals in drinking waters from Mount Amiata (Tuscany, Italy). Possible risks from arsenic for public health in the Province of Siena, Sci. Total Environ. 327 (2004) 41-51.

[4] P.L. Smedley, D.G. Kinniburgh, A review of the source, behaviour and distribution of arsenic in natural waters, Appl. Geochem. 17 (2002) 517-568.

[5] B. Nath, J.-S. Jean, M.-K. Lee, H.-J. Yang, C.-C. Liu, Geochemistry of high arsenic groundwater in Chia-Nan plain, Southwestern Taiwan: possible sources and reactive transport of arsenic, J. Contam. Hydrol. 99 (2008) 85-96.

[6] J. Bundschuh, P. Bhattacharya, J. Hoinkis, N. Kabay, J.-S. Jean, M.I. Litter, Groundwater arsenic: from genesis to sustainable remediation, Water Res. 44 (2010) 5511.

[7] O. Gunduz, C. Simsek, A. Hasozbek, Arsenic pollution in the groundwater of Simav Plain, Turkey: its impact on water quality and human health, Water Air Soil Pollut. 205 (2010) 43-62.

[8] E.W. Brennan, W.L. Lindsay, The role of pyrite in controlling metal ion activities in highly reduced soils, Geochim. Cosmochim. Acta 60 (1996) 3609-3618.

[9] A.L. Foster, G.E. Brown, T.N. Tingle, G.A. Parks, Quantitative arsenic speciation in mine tailings using X-ray absorption spectroscopy, Am. Mineral. 83 (1998) 553-568.

[10] K.S. Savage, T.N. Tingle, P.A. O'Day, G.A. Waychunas, D.K. Bird, Arsenic speciation in pyrite and secondary weathering phases, Mother Lode Gold District, Tuolumne County, California, Appl. Geochem. 15 (2000) 1219-1244.

[11] S.C. Peters, J.D. Blum, The source and transport of arsenic in a bedrock aquifer New Hampshire, USA, Appl. Geochem. 18 (2003) 1773-1787.

[12] P.A. O'Day, D. Vlassopoulos, R. Root, N. Rivera, The influence of sulfur and iron on dissolved arsenic concentrations in the shallow subsurface under changing redox conditions, Proc. Natl. Acad. Sci. U.S.A. 101 (2004) 13703-13708.

[13] S. Kar, J.P. Maity, J.-S. Jean, C.-C. Liu, B. Nath, H.-J. Yang, J. Bundschuh, Arsenicenriched aquifers: occurrences and mobilization of arsenic in groundwater of Ganges Delta Plain, Barasat, West Bengal, India, Appl. Geochem. 25 (2010) 1805-1814.

[14] J.M. Ballantyne, J.N. Moore, Arsenic geochemistry in geothermal systems, Geochim. Cosmochim. Acta 52 (1988) 475-483.

[15] M.Y. Celik, E. Sabah, The geological and technical characterization of Ömer-Gecek geothermal area and the environmental impact assessment of geothermal heating system in Afyon, Turkey, Environ. Geol. 41 (2002) 942-953.

[16] G. Tarcan, U. Gemici, Effects of the contaminants from Turgutlu-Urganlı thermomineral waters on cold ground and surface waters, Bull. Environ. Contam. Toxicol. 74 (2005) 485-492.

[17] M.S. Dogdu, C.S. Bayari, Environmental impact of geothermal fluids on surface water, groundwater and streambed sediments in the Akarcay Basin, Turkey, Environ. Geol. 47 (2005) 325-340.

[18] U. Gemici, G. Tarcan, Hydrogeological and hydrochemical feature of the Heybeli Spa, Afyon Turkey: arsenic and the other contaminants in the thermal waters, Bull. Environ. Contam. Toxicol. 72 (2004) 1107-1114.

[19] A. Baba, H. Ármannsson, Environmental impact of the utilization of a geothermal area in Turkey, Energy Source 1 (2006) 267-278.

[20] U. Gemici, G. Tarcan, Distribution of boron in thermal waters of western Anatolia, Turkey, and examples of their environmental impacts, Environ. Geol. 43 (2002) 87-98.

[21] Z. Demirel, N. Yildirim, Boron pollution due to geothermal wastewater discharge into the Buyuk Menderes River, Turkey, Int. J. Environ. Pollut. 18 (2002) 602-608.

[22] A. Baba, Geothermal environmental impact assessment with special reference to the Tuzla Geothermal Area, Canakkale-Turkey, Geothermal Training Programme Book, Iceland, 2003, pp. 75-114.

[23] J.F. Dewey, A.M.C. Şengör, Aegean and surrounding regions: complex multiplate and continuum tectonics in a convergent zone, Geol. Soc. Am. Bull. Part 1 90 (1979) 84-92. 
[24] Y. Yılmaz, Ş.C. Genç, O.F. Gürer, M. Bozcu, K. Yılmaz, Z. Karacık, Ş. Altunkaynak, A. Elmas, When did the western Anatolian grabens begin to develop? in: E. Bozkurt, J.A. Winchester, J.D.A. Piper (Eds.), Tectonics and Magmatism in Turkey and the Surrounding Area, 173, Geological Society of London, Special Publication, 2000, pp. 353-384.

[25] Y. Yılmaz, S..C. Genç, Z. Karacık, S.. Altunkaynak, Two contrasting magmatic associations of NW Anatolia and their tectonic significance J. Geodyn. 31 (2001) 243-271.

[26] G. Tarcan, S. Filiz, U. Gemici, Geology and geochemistry of the Salihli geothermal fields, Turkey, in: Proceedings of WGC-2000 World Geothermal Congress, 28 May-10 June, Congress Kyushu-Tohoku, Japan, 2000, pp. 1829-1834.

[27] G. Seyitoğlu, Late Cenozoic tectono-sedimentary development of Selendi and Usak-Güre basins: a contribution to the discussion on the development of east-west and north- trending basins in western Turkey, Geol. Mag. 134(1997) $163-175$.

[28] C.-C. Liu, J.-S. Jean, B. Nath, M.-K. Lee, L.-I. Hor, K.-H. Lin, J.P. Maity, Geochemical characteristics of the fluids and muds from two southern Taiwan mud volcanoes: implications for water-sediment interaction and groundwater arsenic enrichment, Appl. Geochem. 24 (2009) 1793-1802.

[29] W. Reuter, L. Davidowski, K. Neubaur, J. Di Bussolo, Speciation of five arsenic compounds in urine by HPLC/ICP-MS, in: Application Note, Perkin Elmer, Inc., 2003, 8 p.

[30] B. Chen, H. Liu, Relationships between phytoplankton growth and cell size in surface oceans: interactive effects of temperature, nutrients, and grazing, Limnol. Oceanogr. 55 (2010) 965-972.

[31] B. Planar-Friedrich, L. Jacqueline, R.B. McCleskey, D.K. Nordstrom, D. Wallschläger, Thioarsenates in geothermal waters of Yellowstone National Park: determination, preservation, and geochemical importance, Environ. Sci. Technol. 41 (2007) 5245-5251.

[32] J.A. Wilkie, J.G. Hering, Rapid oxidation of geothermal arsenic(III) in steamwaters of the eastern Sierra Nevada, Environ. Sci. Technol. 32 (1998) 657-662.
[33] L. Cumbal, J. Bundschuh, V. Aguirre, E. Murgueitio, I. Tipán, C. Chavez, The origin of arsenic in waters and sediments from Papallacta lake in Ecuador, in: J. Bundschuh, M.A. Armienta, P. Birkle, P. Bhattacharya, J. Matschullat, A.B. Mukherjee (Eds.), Natural Arsenic in Groundwater of Latin America, 1, CRC Press/Balkema Publisher, Leiden, The Netherlands, 2009, pp. 81-90.

[34] WHO (World Health Organization), WHO Guidelines for Drinking Water Quality, Health Criteria and Other Supporting Information, vol. 2, WHO, Geneva, 1993.

[35] M. Alsina, I. Saratovsky, J.F. Gaillard, P.A. Pasten, Arsenic speciation in solid phases of geothermal fields, in: M.O. Barnett, D.B. Kent (Eds.), Adsorption of Metals by Geomedia II: Variables, Mechanisms, and Model Applications, Elsevier, Amsterdam, The Netherlands, 2007, pp. 17-440.

[36] P. Birkle, B. Merkel, Environmental impact by spill of geothermal fluids at the geothermal field of Los Azufres, Michoacan, Mexico, Water Air Soil Pollut. 124 (2000) 371-410.

[37] A. Baba, G. Yuce, O. Deniz, D.Y. Ugurluoglu, Hydrochemical and isotopic composition of Tuzla geothermal field (Canakkale-Turkey) and its environmental impacts, Environ. Forensics 10 (2009) 144-161.

[38] N. Aksoy, C. Şimşek, O. Gunduz, Groundwater contamination mechanism in a geothermal field: a case study of Balcova, Turkey, J. Contam. Hydrol. 103 (2009) 13-28.

[39] K. Tyrovola, N.P. Nikolaidis, N. Veranis, N. Kallithrakas-Kontos, P.E. Koulouridakis, Arsenic removal from geothermal waters with zero-valent iron-effect of temperature, phosphate and nitrate, Water Res. 40 (2006) 2375-2386.

[40] H. Sözbilir, B. Uzel, Ö. Sümer, U. İnci, Y. Ersoy, T. Koçer, R. Demirtaş, C. Özkaymak, Evidence for a kinematically linked E-W trending İzmir Fault and NE-trending Seferihisar Fault: kinematic and paleoseismogical studies carried out on active faults forming the İzmir Bay, Western Anatolia, Türkiye Jeoloji Bülteni. 51 (2008) 91-114.

[41] MTA, Geological Map of Turkey, General Directorate of Mineral Research and Exploration (MTA), Ankara, 2002 http://www.mta.gov.tr/v1.0/english/ index.php 